\title{
Perubahan Kualitas Hidup dan Nilai CD4+ Pasien HIV/AIDS dengan Pemberian Ramuan Jamu Imunostimulan di Sragen
}

\author{
Peristiwan R. W. Astana, Danang Ardiyanto, Tofan A. Mana \\ Balai Besar Penelitian dan Pengembangan Tanaman Obat dan \\ Obat Tradisional, Karanganyar, Indonesia
}

\begin{abstract}
Abstrak
Kualitas hidup merupakan salah satu penilaian tingkat keberhasilan suatu terapi. Kualitas hidup yang tinggi akan meningkatkan tingkat kesembuhan serta menurunkan morbiditas dan mortalitas penyakit. Studi ini dilakukan dalam rangka program Saintifikasi Jamu untuk mendapatkan informasi tentang ramuan jamu imunostimulan dalam meningkatkan kualitas hidup penderita HIV/AIDS. Penelitian ini dilakukan pada bulan Juni sampai Oktober tahun 2015 di Komisi Penanggulangan AIDS (KPA) Kabupaten Sragen. Ramuan jamu imunostimulan dapat diberikan sebagai terapi komplementer bersama terapi antiretroviral (ARV). Ramuan jamu yang digunakan adalah 14 gram rimpang temulawak (Curcuma xanthorrhiza), 14 gram temu mangga (Curcuma mangga), dan 14 gram herba meniran (Phyllantus niruri) dalam bentuk rebusan dibandingkan plasebo. Penelitian ini menggunakan metode quasi-experimental pre dan posttest dengan total 60 subjek penderita HIV/AIDS di Sragen. Intervensi dilakukan selama 28 hari dengan mengamati skor World Health Organization Quality of Life-HIV BREF (WHOQOL-HIV $\mathrm{BREF}$ ) dan nilai CD4+. Hasil penelitian menunjukkan bahwa ramuan jamu imunostimulan menaikkan rata-rata skor WHOQOL-HIV BREF pada domain psikologi, kemandirian, dan kesehatan umum secara bermakna ( $p=0,014 ; 0,030 ; 0,003)$ dan mempertahankan nilai CD4+ subjek ramuan jamu. Ramuan jamu memberikan perubahan terhadap kualitas hidup subjek terutama pada domain psikologi, kemandirian, dan kesehatan umum serta mempertahankan nilai CD4+.
\end{abstract}

Kata kunci: CD4+, kualitas hidup, ramuan jamu

\section{Changes in Quality of Life and CD4+ Value on HIV/AIDS Patients with Immunostimulant Jamu Formula in Sragen Regency}

\begin{abstract}
Quality of life is one of parameters to assess a theurapetic goal. Higher quality of life will increase percentage of survival as well as decrease morbidity and mortality of disease. This study was a part of Saintifikasi Jamu program, and aimed to provide information about efficacy of immunostimulant herb formula in improving quality of life HIV/AIDS patients. Immunostimulant jamu formula was given as complementary therapy along with antiretroviral (ARV) therapy. The jamu formula consisted of $14 \mathrm{~g}$ java turmeric (Curcuma xanthorrhiza) rhizome, 14g mango turmeric (Curcuma mangga) rhizome, and 14g meniran (Phyllantus niruri) herbs. The jamu formula was given for 28-day intervention and compared with placebo. This research was conducted on June-October 2015 at National AIDS Commission of Sragen Regency, Central Java. This study used quasi experimental pre and posttest method, involving 60 participants whom diagnosed with HIV/AIDS in Sragen Regency. The results showed that the immunostimulant jamu formula increased the mean scores of World Health Organization Quality of Life-HIV BREF (WHOQOL-HIV BREF) in psychology, independence, and general health domain significantly $(\mathrm{p}=0.014 ; 0.030 ; 0.003)$ and maintained the $\mathrm{CD} 4+$ values. Immunostimulant jamu formula changes the quality of life of subjects especially in the domain of psychology, independence, and general health, and can maintain the CD4+ values.
\end{abstract}

Keywords: CD4+, jamu formula, quality of life

Korespondensi: dr. Peristiwan R. W. Astana, Balai Besar Penelitian dan Pengembangan Tanaman Obat dan Obat Tradisional, Karanganyar, Jawa Tengah 57792, Indonesia, email: drwdhiastana@gmail.com

Naskah diterima: 27 Februari 2018, Diterima untuk diterbitkan: 18 Oktober 2018, Diterbitkan: 1 Desember 2018 


\section{Pendahuluan}

Terdapat satu kasus Human Imunodeficiency Virus/Acquired Imunodeficiency Syndrome (HIV/AIDS) baru setiap 25 menit di Indonesia. Setiap lima kasus HIV/AIDS, satu di antaranya berusia di bawah 25 tahun. ${ }^{1}$ Kabupaten Sragen menjadi salah satu kabupaten dengan risiko tinggi penyebaran HIV/AIDS di Jawa Tengah. Jumlah orang dengan HIV/AIDS (ODHA) di Sragen mencapai 400 orang berdasarkan data tahun 2015. Penanggulangan HIV/AIDS di kabupaten Sragen yang belum sepenuhnya dijalankan secara maksimal menjadi penyebab penanganan kasus ini seperti berjalan di tempat. ${ }^{2}$

Terapi antiretroviral (ARV) merupakan satu-satunya pengobatan HIV/AIDS. Salah satu masalah dalam pemberian ARV yang menjadi perhatian adalah efek samping yang merugikan, seperti mual, anxietas, anoreksia, insomnia, serta adanya gangguan penglihatan dan pengecapan. Efek samping tersebut dapat memengaruhi kualitas hidup penderita HIV/ $\mathrm{AIDS}^{3}$ dan dapat berakibat pada berkurangnya kepatuhan pasien sehingga efektivitasnya menjadi belum optimal. Adanya peningkatan kualitas hidup pada ODHA juga merupakan faktor yang perlu diperhatikan. Semakin tinggi kualitas hidup ODHA, semakin tinggi pula kemampuannya dalam mengatasi penyakit tersebut. ${ }^{4}$ Oleh karena itu, diperlukan suatu terobosan untuk mengurangi efek samping pengobatan dan meningkatkan kualitas hidup penderita.

Jamu telah lama digunakan untuk menjaga kesehatan dan mengobati penyakit. Budaya minum jamu sangat erat dengan kebudayaan masyarakat. Hal ini diperkuat dengan hasil Riskesdas tahun 2013 bahwa sebanyak 46,4\% penduduk Jawa Tengah menggunakan jamu sebagai pengobatan tradisional, ${ }^{5}$ dan terdapat potensi untuk menjadikan jamu sebagai terapi komplementer bagi pasien HIV/AIDS.

Penurunan daya tahan tubuh penderita HIV/AIDS berakibat pada munculnya infeksi oportunistik dan juga berbagai komplikasi. Seringkali kematian ODHA disebabkan oleh komplikasi yang dideritanya, oleh karena itu diperlukan suatu imunostimulan yang dapat meningkatkan daya tahan tubuh ODHA guna mengurangi terjadinya infeksi. ${ }^{6}$ Peningkatan daya tahan tubuh diperlukan untuk perubahan kualitas hidup ODHA sehingga ODHA dapat menjalankan tugasnya dengan baik. Penelitian ini bertujuan untuk mendapatkan bukti ilmiah mengenai khasiat ramuan jamu imunostimulan terhadap perubahan kualitas hidup dan nilai CD4+ dari penderita HIV/AIDS di Kabupaten Sragen.

\section{Metode}

Penelitian ini dilakukan oleh jejaring dokter Saintifikasi Jamu di Kabupaten Sragen, dan berjalan mulai Maret sampai dengan Desember 2015. Desain penelitian menggunakan quasi experimental pre and posttest dengan intervensi selama 28 hari. Persetujuan etik didapatkan dari Komisi Etik Badan Litbang Kesehatan Kementerian Kesehatan Republik Indonesia dengan nomor LB.02.02/5.2/KE.418/2015.

Bahan baku yang dipakai sebagai simplisia diambil dari Magelang dan kebun Balai Besar Litbang Tanaman Obat dan Obat Tradisional, (B2P2TOOT) Tawangmangu. Determinasi dan standarisasi dilakukan di laboratorium B2P2TOOT. Simplisia yang telah memenuhi standar lalu dikemas dengan dosis yang sesuai yaitu dalam satu kemasan untuk sehari. Satu kemasan ini mengandung sebanyak 14 gram rimpang temulawak, 14 gram temu mangga, dan 14 gram herba meniran, yang direbus dengan $600 \mathrm{ml}$ air dan diminum 2 kali sehari. Pembanding yang digunakan pada penelitian ini adalah plasebo berisi pati yang diminum 1 kali sehari. Setiap subjek penelitian didampingi seorang pengawas minum jamu (keluarga atau teman) yang ditunjuk oleh subjek penelitian. Pengawas minum jamu bertugas menyiapkan ramuan jamu siap minum dengan berdasarkan 
penjelasan dokter peneliti.

Penelitian ini menggunakan rebusan simplisia rimpang temulawak (Curcuma xanthorrhiza), temu mangga (Curcuma mangga), dan herba meniran (Phyllantus niruri). Kandungan meniran yang berupa alkoloid dan saponin, beraktivitas menstimulasi sel yang berfungsi sebagai pertahanan tubuh yaitu interferon dan interleukin. Adanya flavonoid dan senyawa fenol berperan dalam mengikat radikal bebas. Kerusakan sel yang cepat dipengaruhi oleh banyaknya radikal bebas yang tinggi di dalam tubuh. Aktivitas pengikatan radikal bebas oleh flavonoid dan senyawa fenol disebut dengan antioksidan. ${ }^{7}$ Secara umum, mekanisme zat aktif dalam tanaman obat bersifat antioksidan. Antioksidan adalah zat aktif yang memiliki potensi untuk memodulasi sistem imun dan dapat digunakan sebagai komplementer pada terapi ARV. ${ }^{8}$

Temulawak mengandung kurkumin dan xantorrizol yang meningkatkan profilerasi dan diferensiasi sel imun melalui jalur NF$\mathrm{kB}$. Aktivitas minyak atsiri temulawak juga dapat menstimulasi proliferasi limfosit. Ekstrak temulawak mempunyai aktivitas tinggi dalam menghambat radikal bebas yang berpengaruh dalam sistem kekebalan tubuh. ${ }^{9,10}$ Kurkumin memiliki aktivitas antioksidan yang tinggi dalam menurunkan jumlah radikal bebas di dalam tubuh. Selain mengandung kurkumin, temu mangga juga mengandung aktivitas antijamur. Temu mangga memiliki potensi terkuat di antara jenis Zingiberaceae lain. Hal ini bermanfaat bagi penderita HIV/AIDS yang mengalami infeksi jamur karena menurunnya daya tahan tubuh. ${ }^{11,12}$

Subjek dalam studi ini adalah pasien HIV/ AIDS yang menjalani terapi ARV, dengan kriteria inklusinya adalah terdiagnosis HIV/ AIDS dengan usia 20-50 tahun; mendapat terapi ARV dengan rutin; sukarela dan setuju mengikuti penelitian dengan menandatangani lembar persetujuan (informed consent). Kriteria eksklusinya adalah kondisi komorbid seperti penyakit ginjal, hati, jantung berat, karsinoma, penyakit paru berat; faktor psikologis yang menyebabkan pasien tidak dapat mengikuti penelitian; hipersensitif terhadap jamu, diperoleh melalui anamnesis penggunaan jamu atau obat herbal sebelumnya; dan hamil.

Penilaian kualitas hidup penderita dilakukan dengan menggunakan WHOQOL-HIV BREF yang merupakan kuesioner yang dikeluarkan oleh World Health Organization (WHO). Kuesioner ini terdiri dari 26 item pertanyaan yang dibagi ke dalam 7 (tujuh) domain, yakni: (1) fisik, (2) psikologi, (3) kemandirian, (4) hubungan sosial, (5) lingkungan, (6) spiritual, dan (7) kesehatan umum. Metode ini pernah diuji validitasnya pada pasien HIV di Taiwan. Hasil pengujian tersebut menunjukkan metode WHOQOL-HIV BREF valid dan terpercaya. ${ }^{13}$ Adanya peningkatan nilai kuesioner pada tiap kali pengukuran menunjukkan terdapat peningkatan pada kualitas hidup subjek uji. Penelitian kuesioner WHOQOL-HIV BREF yang diterjemahkan ke dalam bahasa Indonesia, membuktikan bahwa kuesioner ini sahih dan handal. ${ }^{14}$

Subjek penelitian diwawancara pada hari ke-0, ke-14, dan ke-28 untuk mendapatkan nilai kuesioner. Pemeriksaan CD4+ dilakukan oleh Laboratorium Prodia Surakarta untuk melengkapi data dalam evaluasi khasiat ramuan jamu. CD4+ merupakan representasi tingkat kerentanan penderita HIV/AIDS terhadap penyakit atau infeksi. Pemeriksaan ini dilakukan pada hari ke-0 dan hari ke-28.

Pengujian distribusi data dilakukan dengan menggunakan uji Kolmogorov-Smirnov. Hasil uji memperlihatkan data terdistribusi normal. Perbandingan karakteristik antara subjek yang mendapat ramuan jamu dengan plasebo dilakukan dengan uji Chi-Square, sedangkan penilaian ada atau tidaknya perubahan setiap domain antara hari ke-0 dengan hari ke-14 dan 28 dalam satu kelompok menggunakan uji T sampel berpasangan. Uji perbedaan skor domain antar kelompok pada hari pengukuran 
Tabel 1 Karakterikstik Subjek Kelompok Ramuan Jamu dan Plasebo

\begin{tabular}{|c|c|c|c|c|}
\hline Karakteristik & Ramuan (n) & Plasebo (n) & Total (n) & Nilai p \\
\hline Usia (tahun) & & & & 0,210 \\
\hline $17-25$ & 2 & 3 & 5 & \\
\hline $26-35$ & 10 & 14 & 24 & \\
\hline $36-45$ & 17 & 12 & 29 & \\
\hline $46-55$ & 1 & 1 & 2 & \\
\hline Jenis Kelamin & & & & 0,654 \\
\hline Laki-laki & 8 & 9 & 17 & \\
\hline Perempuan & 22 & 21 & 43 & \\
\hline Status Pernikahan & & & & 0,116 \\
\hline Belum menikah & 2 & 1 & 3 & \\
\hline Menikah & 14 & 16 & 30 & \\
\hline Tinggal bersama & 0 & 0 & 0 & \\
\hline Cerai pisah & 2 & 1 & 3 & \\
\hline Cerai mati & 12 & 12 & 24 & \\
\hline Indeks Massa Tubuh & & & & 0,084 \\
\hline Underweight & 2 & 3 & 5 & \\
\hline Normal & 17 & 20 & 37 & \\
\hline Overweight & 11 & 7 & 18 & \\
\hline
\end{tabular}

yang sama menggunakan uji $\mathrm{T}$ independen. Perbandingan kadar CD4+ hari ke-0 dengan hari ke-28 masing-masing kelompok dilakukan menggunakan uji T sampel berpasangan.

\section{Hasil}

Berdasarkan hasil randomisasi, sebanyak 32 orang masuk dalam kelompok formula jamu, dan 31 orang dalam kelompok obat plasebo. Pada kelompok jamu, terdapat 2 orang drop out dari penelitian karena mengundurkan diri. Pada kelompok obat plasebo, 1 orang drop out karena tidak dapat dihubungi lagi. Pasien yang menyelesaikan penelitian sebanyak 60 subjek yaitu 30 subjek pada kelompok jamu dan 30 subjek pada kelompok plasebo.

Berdasarkan Tabel 1, dapat dilihat bahwa secara stastistik variabel umur, jenis kelamin, pekerjaan dan indek masa tubuh (IMT) subjek penelitian antara kelompok jamu dan plasebo memiliki nilai $\mathrm{p}>0,05$, sehingga disimpulkan bahwa tidak terdapat perbedaan bermakna antara karakterikstik subjek di antara kedua kelompok. Sebanyak 53 subjek termasuk dalam usia kerja dan lebih dari separuh (72\%) adalah perempuan.

Terdapat 7 (tujuh) domain yang diukur, yaitu domain fisik, psikologis, kemandirian, sosial, lingkungan, spiritual, hubungan sosial dan kesehatan umum. Adanya kenaikan ratarata skor masing-masing domain menandakan adanya perbaikan dalam kualitas hidup subjek setelah perlakuan. Dari Tabel 2, dapat dilihat bahwa nilai skor rata-rata tertinggi subjek jamu dari hasil pengisian kuesioner hari ke-0 adalah 14,90 pada domain spiritual. Demikian halnya pada subjek plasebo, domain spiritual memiliki rata-rata skor tertinggi yaitu 15,60. Di lain pihak, rata-rata terendah pada subjek jamu yakni dalam domain lingkungan dengan skor 13,58 dan pada subjek plasebo juga dalam domain lingkungan dengan rata-rata 13,71.

Tabel 3 merupakan analisis perbandingan skor WHOQOL-HIV BREF antara pada saat awal intervensi (hari ke-0) dengan hari ke-14 dan 28 pada tiap-tiap kelompok. Subjek jamu mengalami peningkatan yang signifikan $(\mathrm{p}=$ $0,006)$ pada domain kesehatan umum di hari ke-14, sedangkan perbandingan skor hari ke- 
Tabel 2 Rata-Rata Skor WHOQOL-HIV BREF Kelompok Jamu dan Plasebo

\begin{tabular}{lcccccc}
\hline \multirow{2}{*}{ Domain } & \multicolumn{3}{c}{ Ramuan Jamu } & \multicolumn{3}{c}{ Plasebo } \\
\cline { 2 - 7 } & Hari-0 & Hari-14 & Hari-28 & Hari-0 & Hari-14 & Hari-28 \\
\hline Fisik & 14,33 & 14,50 & 14,50 & 15,03 & 15,13 & 15,26 \\
Psikologi & 14,40 & 14,50 & 14,50 & 15,49 & 15,14 & 15,20 \\
Kemandirian & 14,30 & 15,30 & 15,30 & 15,00 & 15,20 & 15,10 \\
Hubungan sosial & 14,56 & 14,76 & 14,76 & 13,86 & 13,56 & 13,73 \\
Lingkungan & 13,58 & 14,05 & 14,03 & 13,71 & 13,81 & 13,88 \\
Spiritual & 14,90 & 14,90 & 15,16 & 15,60 & 15,70 & 15,30 \\
Kesehatan umum & 3,63 & 3,75 & 3,9 & 3,75 & 3,87 & 3,72 \\
\hline
\end{tabular}

28 dengan hari ke-0 memperlihatkan adanya dua domain, yaitu domain psikologi dan kesehatan umum, yang mengalami peningkatan yang signifikan $(\mathrm{p}<0,05)$. Terdapat lima domain yang rata-rata skornya meningkat namun tidak terlihat signifikan secara stastistik ( $p>0,05$ ). Pada kelompok subjek plasebo, domain kesehatan umum mengalami perubahan yang signifikan $(\mathrm{p}<0,05)$ pada perbandingan skor hari ke-14 dengan hari ke-0. Domain lain subjek plasebo mengalami peningkatan namun tidak terlihat signifikan secara stastistik ( $\mathrm{p}>0,05)$.

Pada Tabel 4, dapat dilihat rata-rata skor WHOQOL-HIV BREF antara kelompok subjek jamu dibandingkan plasebo. Perbandingan ini ini dilakukan pada skor hari yang sama yaitu hari ke-0, 14, dan 28. Hasil perbandingan skor hari ke-0, tidak terdapat perbedaan yang signifikan $(\mathrm{p}>0,05)$ antara kelompok jamu dan plasebo. Hal ini menunjukkan baseline skor WHOQOL-HIV BREF kedua kelompok adalah sebanding. Terdapat enam domain yang mengalami peningkatan, namun apabila dibandingkan, hasilnya tidak ada perbedaan yang signifikan antarkedua kelompok subjek $(p<0,05)$. Hanya domain hubungan sosial yang mengalami perubahan yang signifikan baik pada hari ke-14 maupun hari ke-28 dengan masing-masing nilai $\mathrm{p}=0,019$ dan 0,029 .

Setelah diintervensi selama 28 hari, pada parameter CD4+ terdapat peningkatan pada 20 subjek ramuan jamu dan 8 subjek kelompok plasebo. Sebaliknya, terdapat beberapa subjek yang mengalami penurunan CD4+ yaitu 10 subjek pada kelompok jamu dan 8 subjek pada kelompok plasebo.

Tabel 3 Uji T Sampel Berpasangan Rata-Rata Skor WHOQOL-HIV BREF Masing-Masing Kelompok

\begin{tabular}{lcccc}
\hline & \multicolumn{2}{c}{ Ramuan Jamu } & \multicolumn{2}{c}{ Plasebo } \\
& $\begin{array}{c}\text { Hari-0 } \\
\text { dengan } \\
\text { Hari-14 }\end{array}$ & $\begin{array}{c}\text { Hari-0 } \\
\text { dengan } \\
\text { Hari-28 }\end{array}$ & $\begin{array}{c}\text { Hari-0 } \\
\text { dengan } \\
\text { Hari-14 }\end{array}$ & $\begin{array}{c}\text { Hari-0 } \\
\text { dengan } \\
\text { Hari-28 }\end{array}$ \\
& (Nilai p) & (Nilai p) & (Nilai p) & (Nilai p) \\
\hline Fisik & 0,665 & 0,269 & 0,676 & 0,354 \\
Psikologi & 0,684 & $0,014^{*}$ & 0,136 & 0,222 \\
Kemandirian & 0,059 & $0,030^{*}$ & 0,613 & 0,787 \\
Hubungan sosial & 0,532 & 0,406 & 0,293 & 0,670 \\
Lingkungan & 0,133 & 0,050 & 0,601 & 0,382 \\
Spiritual & 0,998 & 0,438 & 0,769 & 0,349 \\
Kesehatan umum & $0,006^{*}$ & $0,003^{*}$ & $0,006^{*}$ & 0,536 \\
\hline
\end{tabular}

*Signifikan bila nilai $\mathrm{p}<0,05$ 
Tabel 4 Uji T Independen Rata-Rata Skor WHOQOL-HIV BREF Antarkelompok

\begin{tabular}{lccc}
\hline \multicolumn{1}{c}{ Domain } & $\begin{array}{c}\text { Hari-0 } \\
\text { (Nilai p) }\end{array}$ & $\begin{array}{c}\text { Hari-14 } \\
\text { (Nilai p) }\end{array}$ & $\begin{array}{c}\text { Hari-28 } \\
\text { (Nilai p) }\end{array}$ \\
\hline Fisik & 0,210 & 0,225 & 0,441 \\
Psikologi & 0,073 & 0,123 & 0,546 \\
Kemandirian & 0,134 & 0,835 & 0,764 \\
Hubungan sosial & 0,087 & $0,019 *$ & $0,029^{*}$ \\
Lingkungan & 0,714 & 0,467 & 0,649 \\
Spiritual & 0,426 & 0,271 & 0,85 \\
Kesehatan umum & 0,425 & 0,437 & 0,202 \\
\hline
\end{tabular}

*Signifikan bila nilai $\mathrm{p}<0,05$

Hasil uji $\mathrm{T}$ sampel berpasangan antara kadar CD4+ pada hari ke-0 dengan hari ke-28 diperoleh nilai $\mathrm{p}=0,210$ (Tabel 3). Tidak terdapat perbedaan bermakna antara rata-rata $\mathrm{CD} 4+$ hari ke-0 dan ke-28. Nilai baseline kedua kelompok adalah sebanding. Pada kelompok subjek jamu, tidak ada perbedaan signifikan pada nilai CD4+ setelah 28 hari perlakuan, sedangkan pada kelompok plasebo, rata-rata CD4+ setelah 28 hari mengalami penurunan dari 432,37 menjadi 388,70. Berdasarkan hasil uji $\mathrm{T}$ sampel berpasangan, didapatkan nilai $p=0,023$. Hal ini menunjukkan bahwa penurunan kadar CD4+ tersebut signifikan secara statistik (Tabel 5).

\section{Pembahasan}

Kualitas hidup subjek ODHA merupakan pandangan setiap individu dalam menjalani kehidupan sehari-hari. Budaya masyarakat dan norma-norma lingkungan berpengaruh terhadap kekhawatiran, tujuan, dan harapan pada ODHA. Penelitian ini memperlihatkan bahwa domain kesehatan umum subjek uji kedua kelompok mulai meningkat pada hari ke-14, sedangkan untuk domain psikologi dan kemandirian terlihat berbeda pada hari ke-28.

Aspek kesehatan umum kelompok subjek jamu maupun plasebo mengalami peningkatan yang signifikan. Kesehatan umum merupakan perspektif dari seorang yang menderita HIV/ AIDS terhadap kondisi kesehatan tubuhnya sendiri. Kepatuhan pasien dalam meminum ARV dapat meningkatkan keyakinan pasien sehingga menaikkan persepsi akan kesehatan mereka. ${ }^{15}$ Pada penelitian ini, aspek kesehatan umum subjek uji kelompok jamu meningkat secara signifikan pada hari ke-14 dan ke-28, sedangkan untuk kelompok plasebo meningkat pada hari ke-14. Hal ini kemungkinan karena tingkat kepatuhan subjek minum jamu atau plasebo selama penelitian tergolong tinggi. Berdasarkan penelitian sebelumnya, aspek persepsi kesehatan umum tidak memberikan pengaruh signifikan terhadap kualitas hidup seseorang. ${ }^{16}$

Domain psikologi dan spiritual memiliki pengaruh terhadap kualitas hidup walaupun tidak sekuat pengaruh domain hubungan sosial, lingkungan, kemandirian dan fisik. ${ }^{17}$ Semakin meningkat skor domain-domain di atas, dapat

Tabel 5 Perbandingan Nilai CD4+ Ramuan Jamu dan Plasebo

\begin{tabular}{lcccccc}
\hline \multirow{2}{*}{ Pengukuran } & \multicolumn{3}{c}{ Ramuan Jamu } & \multicolumn{3}{c}{ Plasebo } \\
\cline { 2 - 7 } & Rata-rata & SD & Nilai $\mathbf{p}$ & Rata-rata & SD & Nilai p \\
\hline Hari ke-0 & 273,47 & 197,771 & - & 432,37 & 241,098 & - \\
Hari ke-28 & 282,20 & 198,668 & 0,21 & 388,70 & 224,118 & $0,023^{*}$ \\
\hline
\end{tabular}

Keterangan: $\mathrm{SD}=$ Standar Deviasi; *Signifikan bila nilai $\mathrm{p}<0,05$ 
dikatakan ada perbaikan pada kualitas hidup subjek. Pada kelompok subjek jamu, domain psikologi dan kemandirian meningkat secara signifikan walaupun tidak ada referensi yang menyebutkan mekanismenya.

Adanya peningkatan pada skor kuesioner WHOQOL-HIV BREF, terutama pada domain hubungan sosial kelompok subjek jamu, dapat menjadi salah satu alasan pemberian jamu ini untuk ODHA. Temulawak dan temu mangga mengandung kurkumin yang secara empiris digunakan untuk meningkatkan kebugaran. ${ }^{18}$ Tingkat kebugaran yang baik akan membantu kemampuan kognitif ODHA dalam melakukan aktivitas sehari-hari. Hubungan sosial seseorang akan meningkat jika pandangan saat menjalani kehidupan sehari-hari juga membaik. ${ }^{19}$

Jumlah normal CD4+ adalah 500-1000 $\mathrm{sel} / \mathrm{mm}^{3}$ darah. Semakin tinggi CD4+, maka akan semakin tinggi juga kemampuan tubuh dalam mempertahankan diri dari komplikasikomplikasi yang berhubungan dengan HIV/ AIDS khususnya mencegah terjadinya infeksi oportunistik. Kenaikan jumlah sel CD4+ pada subjek yang memperoleh jamu dapat menjadi pertimbangan dalam pemberian jamu sebagai suatu komplementer obat HIV/AIDS. Meniran telah terbukti dapat menghambat replikasi virus HIV-1 dengan konsentrasi efektif 50\% di rentang $0,9-7,6 \mu \mathrm{g} / \mathrm{mL}$. Penelitian mengenai ayurveda mencatat penggunaan herba meniran sebagai antivirus. ${ }^{20}$

Penelitian ini memiliki keterbatasan dalam pelaksanaannya. Kualitas hidup merupakan parameter yang dilihat perbedaannya dalam jangka waktu lama. Intervensi yang diberikan selama 28 hari dapat dikatakan relatif singkat untuk mengetahui perubahan kualitas hidup dari subjek penelitian. Pada penelitian ini, penderita HIV/AIDS telah mendapatkan terapi minimal sejak dua tahun sebelumnya. Hal ini mengakibatkan sebagian besar subjek telah menerima keadaan penyakitnya. Oleh karena itu, diperlukan waktu perlakuan yang lebih lama untuk menilai perubahan kualitas hidup penderita HIV/AIDS.

\section{Simpulan}

Hasil penelitian menunjukkan bahwa ramuan jamu imunostimulan memberikan perubahan terhadap kualitas hidup terutama pada domain psikologi, kemandirian, dan kesehatan umum pada penderita HIV/AIDS di Kabupaten Sragen dan mempertahankan nilai CD4+.

\section{Ucapan Terima Kasih}

Terima kasih disampaikan kepada PPI Balai Besar Litbang Tanaman Obat dan Obat Tradisional (B2P2TOOT), dokter, apoteker, analis laboratorium, dokter saintifikasi jamu Kabupaten Sragen, Komisi Penanggulangan AIDS (KPA) Kabupaten Sragen, serta pegawai di Klinik Saintifikasi Jamu Hortus Medicus Tawangmangu.

\section{Pendanaan}

Penelitian ini dibiayai oleh DIPA Balai Besar Penelitian dan Pengembangan Tanaman Obat dan Obat Tradisional Tawangmangu.

\section{Konflik Kepentingan}

Semua penulis menyatakan tidak ada konflik kepentingan dengan penelitian, kepenulisan (authorship), dan atau publikasi artikel ini.

\section{Daftar Pustaka}

1. Unicef Indonesia. Respon terhadap HIV \& AIDS, 2012 [diunduh 3 Januari 2017]. Tersedia dari: http://www.unicef.org/indo nesia /id/A4Unicef Indonesia.

2. Komisi Penanggulangan AIDS (KPA). Buku Saku KPA. Sragen; KPA: 2015.

3. Barus T, Anwar Y, Ginting D. Evaluation of antiretroviral adverse effects and managements on HIV/AIDS patients in 
Penjaringan district primary health centre, North Jakarta, 2013-2015. Soc Clin Pharm Indones J. 2017;2(1):29-37.

4. Handajani YS, Djoerban Z, Irawan, H. Quality of life people living with HIV/ AIDS: Outpatient in Kramat 128 Hospital Jakarta. Acta Med Indones. 2012;44(4): 310-6.

5. Kementerian Kesehatan Republik Indonesia. Riset Kesehatan Dasar (Riskesdas) Tahun 2013. Jakarta: Badan Penelitian dan Pengembangan Kesehatan Kementerian Kesehatan Republik Indonesia; 2014.

6. Smith CJ, Ryom L, Weber R, Morlat P, Pradier C, Reiss P, et al. Trends in underlying causes of death in people with HIV from 1999 to 2011 (D:A:D): A multicohort collaboration. Lancet. 2014;384(9939): 241-8. doi: 10.1016/S0140-6736(14)606 04-8.

7. Oyewo EB, Akanji MA, Adekunle AS. Immunomodulation capabilities of aqueous leaf extract of Phyllanthus amarus in male Wistar Rats. Report Opin. 2012;4(1):2237.

8. Jalil N, Adam AM, Djawad K, Seweng A, Halim R, Adriani A. Comparison of total antioxidant capacity and CD4 in patient with HIV stage I and stage IV. Nusantara Med Sci J. 2017;1:14-21.

9. Miksusanti. Lymphocyte proliferation by temulawak (Curcuma xanthorrhiza) essential oil 2.2. Gas chromatography mass spectrometry (GCMS): Analysis of essential oils from temulawak tuber. Proceedings of International Conference on Bioinformatics and Biomedical Technology (ICCBT); 2012 February 2628; Singapore. Singapore; CBEES: 2012.

10. Dewi M, Aries M, Hardinsyah, Dwiriani CM, Januwati N. Knowledge on health benefit of curcuma and the clinical trial of its effect on humoral immune system in obese adults. Indones J Agricultural Sci. 2012;17(3):166-71.
11. Shukla AC, Zosiamliana JH, Khiangte L, Singh B, Kumar A, Dikshit A. Botanical antimicrobials: An approach from traditional to modern system of drug. Sci Technol J. 2014:2(1);67-76.

12. Jantan I, Harun NH, SeptamaAW, Murad S, Mesaik MA. Inhibition of chemiluminescence and chemotactic activity of phagocytes in vitro by the extracts of selected medicinal plants. J Nat Med. 2011;65(2):400-5. doi: 10.1007/s11418-010-0492-8

13. Hsiung PC, Fang CT, Wu CH, Sheng WH, Chen SC, Wang JD, et al. 2011. Validation of the WHOQOL-HIV BREF among HIV-infected patients in Taiwan. AIDS Care. 2011;23(8):1035-42. doi: 10. 1080/09540121.2010.543881.

14. Nanda NM, Hamzah S, Zubairi Djoerban, Murdani A. Validity and reability test of Indonesian version World Health Organization quality of life-HIV BREF questionnaire to measure the quality of life patients with HIV/AIDS. J Penyakit Dalam Indonesia. 2017;4(3):112-8. doi: 10.7 454/jpdi.v4i3.137

15. Unzila SR, Nadhiroh SR, Triyono EA. Hubungan kepatuhan anti retroviral therapy (ART) satu bulan terakhir dengan kualitas hidup pasien HIV/AIDS di RSUD dr. Soetomo Surabaya. Media Gizi Indonesia. 2016;11(1):24-31. doi: 10.20473/mgiv11 i1.24-31

16. Krägeloh CU, Henning MA, Billington R, Hawken SJ. The relationship between quality of life and spirituality, religiousness, and personal beliefs of medical students. Acad Psychiatry. 2015;39(1):85-9. doi: 10.100 7/s40596-014-01 58-z

17. Superketia IGME, Astuti IW, Lestari MPL. Hubungan antara tingkat spiritualitas dengan tingkat kualitas hidup pada pasien HIV/AIDS di Yayasan Spirit Paramacitta Denpasar. Community Publishing Nursing (COPING). 2016;4(1):49-53.

18. Elfahmi, Herman JW, Kayser O. Jamu: 
Indonesian traditional herbal medicine towards rational phytopharmacological use. J Herb Med. 2014;4(2):51-73. doi: 10. 1016/j.hermed.2014.01.002

19. Muzamil MS, Afriwardi, Martini RD. Hubungan antara tingkat aktivitas fisik dengan fungsi kognitif pada usila di Kelurahan Jati Kecamatan Padang Timur.
Andalas J Health. 2014;3(2):202-5. 20. Wagh VD, Patil SV, Surana SJ, Wagh KV. Medicinal plants used in preparation of polyherbal ayurvedic formulation Chyawanprash. J Med Plants Res Rev. 2013; 7(38):2801-14. doi: 10.5897/JMPR11.16 08 